\title{
Effect of Different Salinity Levels on Population Dynamics and Growth of the Cyclopoid Copepod Oithona nana
}

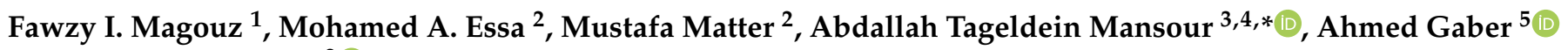 \\ and Mohamed Ashour ${ }^{2}$ (1) \\ 1 Department of Animal Production, Faculty of Agriculture, Kafrelsheikh University, \\ Kafrelsheikh 33516, Egypt; Fozymagouz22@yahoo.com \\ 2 National Institute of Oceanography and Fisheries (NIOF), Cairo 11516, Egypt; messa51@yahoo.com (M.A.E.); \\ mhsy4@yahoo.com (M.M.); microalgae_egypt@yahoo.com (M.A.) \\ 3 Animal and Fish Production Department, College of Agricultural and Food Sciences, King Faisal University, \\ P.O. Box 420, Al-Ahsa 31982, Saudi Arabia \\ 4 Fish and Animal Production Department, Faculty of Agriculture (Saba Basha), Alexandria University, \\ Alexandria 21531, Egypt \\ 5 Department of Biology, College of Science, Taif University, P.O. Box 11099, Taif 21944, Saudi Arabia; \\ a.gaber@tu.edu.sa \\ * Correspondence: amansour@kfu.edu.sa; Tel.:+966-56-508-9202
}

Citation: Magouz, F.I.; Essa, M.A.; Matter, M.; Mansour, A.T.; Gaber, A.; Ashour, M. Effect of Different Salinity Levels on Population Dynamics and Growth of the Cyclopoid Copepod Oithona nana. Diversity 2021, 13, 190. https://doi.org/10.3390/d13050190

Academic Editor: Benny Kwok Kan Chan

Received: 9 April 2021

Accepted: 27 April 2021

Published: 29 April 2021

Publisher's Note: MDPI stays neutral with regard to jurisdictional claims in published maps and institutional affiliations.

Copyright: (c) 2021 by the authors. Licensee MDPI, Basel, Switzerland. This article is an open access article distributed under the terms and conditions of the Creative Commons Attribution (CC BY) license (https:/ / creativecommons.org/licenses/by/ $4.0 /)$.

\begin{abstract}
Copepods are one of the most abundant and diverse live food sources for mesopelagic and bathypelagic fishes and crustaceans. They could contribute to the overlap of the transition period from live feed to an artificial weaning diet in marine larvae production. However, the culture conditions still need optimization to provide sufficient production to cover the increasing demand for marine hatcheries. Therefore, the present study investigated the effects of different salinity levels $(5,10,15,20,25$, and $30 \mathrm{ppt})$ on the population growth, growth rate, and population composition (males, females, copepodite, and nauplii ratio) of the marine copepod, Oithona nana. The experiment continued for 15 days, under laboratory-controlled conditions of temperature $\left(27 \pm 1^{\circ} \mathrm{C}\right)$, $\mathrm{pH}(7.7 \pm 0.15)$, and continuous gentle aeration in $30 \mathrm{~L}$ glass aquaria. The copepod culture aquaria were supplemented with a mixture of soybean and yeast $\left(0.5 \mathrm{~g} 10^{-6}\right.$ individual $\left.^{-1} 24-\mathrm{h}^{-1}\right)$ as a feed source. The highest significant population growth and population growth rate of $O$. nana were achieved with a salinity level of $20 \mathrm{ppt}$. Regarding population composition, O. nana cultured at the salinity level of 20 ppt recorded the highest significant percentages of copepodite and nauplii. The results concluded that copepod, O. nana, is capable of withstanding abrupt changes in the salinity, but there are limits to their tolerance, with an optimal salinity level of 20 ppt. This salinity level achieved the highest population growth and the highest percentages of copepodite and nauplii of marine Copepoda, O. nana.
\end{abstract}

Keywords: aquaculture; live feeds; salinity; copepodite; growth; population composition

\section{Introduction}

Aquaculture is one of the fastest-growing global industries that supply animal protein to face the demand of an increasing global population [1]. To realize successful and sustainable marine aquaculture applications, continuous isolation and screening are required to discover native aquatic organisms [2]. Copepods are the most important group that links the primary producers with the secondary consumers in aquatic ecosystems. In marine hatcheries, the production of the appropriate live feed is considered one of the most important bottleneck factors that limit the success of marine larvae production [3-7]. Besides rotifer and Artemia, which were extensively utilized as prey for shrimp and fish larvae [8-17], copepods are the most suitable live prey [3-6]. In the wild, among zooplankton, copepods are the primary prey of mesopelagic and bathypelagic fish [18,19]. Copepods are 
remarkable because they are the most abundant and diverse under different environmental conditions [10].

The copepod family Oithonidae comprises an important part of the copepod biomass in temperate areas, displaying high population densities [20]. The Oithonidae family are the most efficient free-living cyclopoids in the marine epipelagic ecosystem. They are small (usually less than $1 \mathrm{~mm}$ in body length) and exist in the ocean at relatively high densities [21]. Oithona nana is the most distributed Oithonidae species that comprises more than $90 \%$ and $67 \%$ of the abundance and the biomass, respectively, of the zooplankton in many coastal areas [22]. Although the ecological importance of this Oithonidae species is high, the literature is sparse about its reproduction and ecosystem conditions [20,23,24].

Delicate determination of the population dynamics of copepods in the mass production system is very important in predicting the quantity of production and providing the hatchery's requirement of live food, which can be achieved successfully in a laboratory environment under controlled ranges similar to environmental conditions [25]. It is very important to identify the optimum environmental conditions for a potential aquaculture species to establish a population of that organism, which will be positively reflected in the revenue of production $[8,26,27]$. Such information is important for the successful culturing of copepods to be utilized as live feed in the aquaculture industry [28].

Among all the environmental parameters, temperature and salinity have been reported as the major variables affecting copepod species. The salinity significantly affects the population dynamics of the copepod O. rigida [29]. Many authors have reported that the variation in salinity strongly influences population growth, growth rate, composition, survival, and hatching success of several species of marine copepods [25,30-39]. Therefore, studying the effects of salinity levels on marine copepod production is still required to find out the ideal concentration for marine aquaculture. Milione et al. [36] reported that the highest population growth of calanoid copepod $A$. sinjiensis, cultured at different salinity levels ranging from 10 to $50 \mathrm{~g} \mathrm{~L}^{-1}$, was reported at $30 \mathrm{~g} \mathrm{~L}^{-1}$. Pan et al. [39] studied the effects of different salinity levels (0-35 ppt) on the population growth and composition of different developmental stages of the copepod Apocyclops royi and reported that salinity levels had varying effects on $A$. royi regarding its composition at different developmental stages. The current study aims to evaluate the population dynamics and growth of the cyclopoid copepod O. nana cultured under different salinity levels.

\section{Materials and Methods}

\subsection{Isolation and Stock Culture of Copepods}

The studied copepod, O. nana, was isolated during the 2017 spring season from earthen ponds at El-Max Research Station, Alexandria Branch of the National Institute of Oceanography and Fisheries, (NIOF), Egypt. During the collection period, the water quality factors of salinity $(31 \pm 1 \mathrm{ppt})$, temperature $\left(23 \pm 2{ }^{\circ} \mathrm{C}\right)$, and $\mathrm{pH}(7.37 \pm 0.10)$ of earthen ponds were recorded at noon. Copepod samples were collected using the protocol described by Abo-Taleb et al. [9]. Morphological identifications of isolated adult individuals were firstly examined under a binocular stereomicroscope (Optika Microscopes, B190/B-290, Italy) and then taxonomically characterized by the Hydrobiology Lab., Marine Environment Division, NIOF, Egypt. The adult individuals of $O$. nana were cultured in stock tanks under laboratory-controlled conditions $\left(27 \pm 1^{\circ} \mathrm{C}, 30 \pm 1 \mathrm{ppt}, \mathrm{pH} 7.7 \pm 0.15\right.$, and continuous gentle aeration) and enriched with a native identified marine microalga, Nannochloropsis oceanica, NIOF15/001 at a concentration of $2 \times 10^{6}$ cells $^{-1} \mathrm{ml}^{-1} \mathrm{day}^{-1}$ [40], which was diluted from the algal culture medium $\left(5 \times 10^{6}\right.$ cells $^{-1} \mathrm{ml}^{-1}$ day $\left.^{-1}\right)$ [13].

\subsection{Experimental Design}

Before the start of the experiment, the adult individuals of $O$. nana were collected from the stock tanks and transferred to the new culture water for $24 \mathrm{~h}$ as a gut-evacuation period $[39,41]$. The adult individuals of copepod $O$. nana (average size: $625 \mu \mathrm{m}$ ) were cultured in an experimental glass tank with $30 \mathrm{~L}$ of $1 \mu \mathrm{m}$ bag-filtered, chlorine-disinfected 
seawater (30 ppt). According to references [26,38], the standard culture densities for copepods species ranged from 0.5 to $1.0 \mathrm{~mL}$. Therefore, the initial stock density of $O$. nana in the current study was selected according to the previous reference with approximately 1 individual $\mathrm{ml}^{-1}$ (about 1000 ind. $\mathrm{L}^{-1}$ ).

In the current study, the effects of six salinity levels $(5,10,15,20,25$, and $30 \mathrm{ppt}$, with three replicates for each level) on population dynamics, including growth, growth rate, and population composition (male, female, copepodite, and nauplii) of marine isolated copepods, O. nana, were determined. To prepare the salinity levels, saline water (30 $\pm 1 \mathrm{ppt})$ was diluted with distilled water to obtain the needed level. During the experiment, all treatments were fed a mixture of commercial-grade baker's yeast, Saccharomyces cerevisiae (supplied by Starch, Yeast and Detergents Company, Alexandria, Egypt), and a very finely ground commercial grade of soybean (supplied by Fish Feed Factory, located in Alexandria, Egypt), with a concentration of $0.5 \mathrm{~g} 10^{-6}$ individual $24-\mathrm{h}^{-1}$ of each feed source.

The needed concentration of feed was estimated depending on the previously counted copepods' individual $\mathrm{mL}^{-1}$, which was measured every three days (day-0, day-3, day-6, day-9, day-12, and day-15) [42,43]. The experiment was continued for 15 days (from day-0 to day-15), under laboratory-controlled conditions of temperature $\left(27 \pm 1{ }^{\circ} \mathrm{C}\right.$, using a digital thermometer) and $\mathrm{pH}(7.7 \pm 0.15)$. The replicates were conducted without water replacement and were supplied with gentile aeration to keep the dissolved oxygen (DO) over 4 mg/l (measured using Oxymeter, HI-9142, HANNA Instruments, Woonsocket, RI, USA). In all salinity levels, the ammonia $\left(\mathrm{NH}_{3}\right)$ concentration (measured using digital multi-meter, Crison Model MM41, Spain) was $<0.45 \pm 0.05 \mathrm{mg} \mathrm{L}^{-1}$.

\subsection{Tested Parameters}

\subsubsection{Population dynamics}

Every three days, from each replicate, a constant volume $(25 \mathrm{ml})$ of culture water was taken to calculate the population growth of copepods (ind. $\mathrm{ml}^{-1}$ ). The population growth rate $(r)$ was calculated depending on the population growth, according to the equation of Yin et al. [44], as the following:

$$
\mathrm{R}=\left(\ln \mathrm{N}_{\mathrm{t}}-\ln \mathrm{N}_{0}\right) / \mathrm{t}
$$

where $\mathrm{N}_{0}$ and $\mathrm{N}_{t}$ are the initial and final population densities, respectively, and $t$ is the incubation time in days.

\subsubsection{Population Composition}

To determine the percentage of different developmental stages (male, female, nauplii, and copepodite) of population composition, approximately one hundred individuals were randomly harvested from each replicate (using a plankton net of a $38 \mu \mathrm{m}$ mesh), and fixed with a $4 \%$ formalin solution, and investigated on slides under a microscope (Optika Microscopes, B190/B-290, Ponteranica, Italy).

\subsection{Data Analysis}

The statistical analyses were determined using SPSS Ver. 16. The data are presented as the mean \pm standard error $(n=3)$. To compare differences among individual means at a significance level of $p \leq 0.05$, all variables were calculated using one-way analysis of variance (ANOVA) followed by Duncan's multiple-range tests.

\section{Results}

Data presented in Figure 1 show that the population growth of marine isolated copepoda, O. nana, was significantly affected by different salinity levels $(5,10,15,20,25$, and $30 \mathrm{ppt}$ ). Among all salinity levels, the population growth of $O$. nana cultured at a level of 20 ppt exhibited the highest significant $(p \leq 0.05)$ population growth in all investigated days, as follows: day-3 (1300 ind. $\left.\mathrm{L}^{-1}\right)$, day-6 (1800 ind. $\left.\mathrm{L}^{-1}\right)$, day-9 $\left(2800 \mathrm{ind}\right.$. $\left.\mathrm{L}^{-1}\right)$, day-12 (3533 ind. $\mathrm{L}^{-1}$ ), and day-15 (4733 ind. $\mathrm{L}^{-1}$ ). 


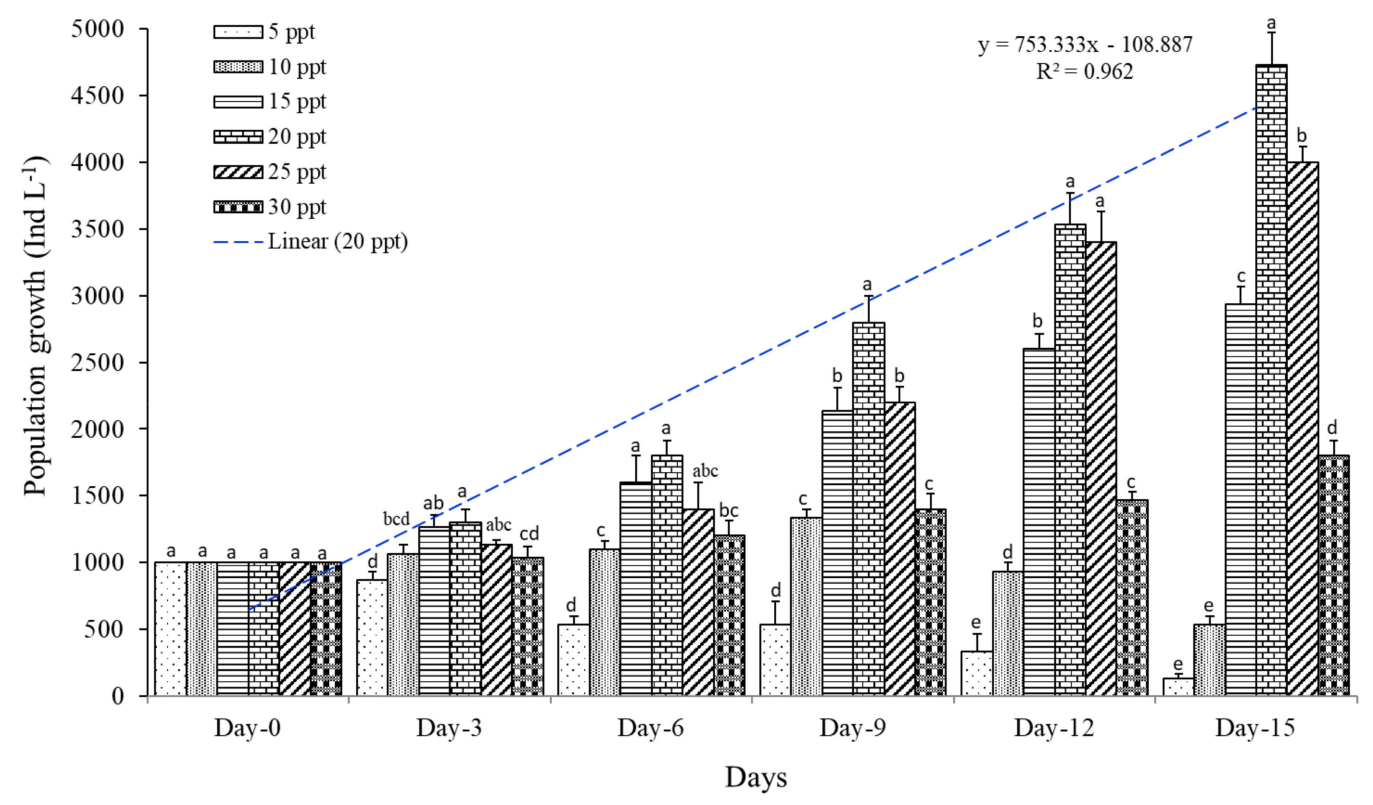

Figure 1. Effect of different salinity levels on the population growth (individual $1^{-1}$ ) of Copepoda, Oithona nana. Data are presented as the mean \pm standard errors. The letters $(a, b$, and $c)$ above each bar indicate the significant differences $(p \leq 0.05)$ between different diets in the same day. The blue dash line is the linear regression of population growth of $O$. nana reared at 20 ppt salinity level over time.

As presented in Figure 1, at the salinity level of $20 \mathrm{ppt}$, the increase in population growth followed a linear trend with $R^{2}=0.96$ and $y=753.333 x-108.887$. Between measurements, the salinity level of 25 ppt exhibited the second-highest population growth of $O$. nana, while the lowest population growth was reported at $5 \mathrm{ppt}$. At the end of the experiment, day-15, the highest significant increase in population growth was obtained by $O$. nana cultured at the salinity level of $20 \mathrm{ppt}\left(4733\right.$ ind. $\left.\mathrm{L}^{-1}\right)$, followed by $25 \mathrm{ppt}$ (4000 ind. $\left.\mathrm{L}^{-1}\right), 15 \mathrm{ppt}\left(2933\right.$ ind. $\left.\mathrm{L}^{-1}\right), 30 \mathrm{ppt}\left(1800\right.$ ind. $\left.\mathrm{L}^{-1}\right)$, and $10 \mathrm{ppt}\left(533\right.$ ind. $\left.\mathrm{L}^{-1}\right)$. Meanwhile, the copepod population maintained in the salinity levels of 5 and $10 \mathrm{ppt}$ significantly decreased compared to other treatments from the initial stocking density. In addition, the effect of salinity on population growth after 15 days revealed a polynomial second-order regression with a strong correlation $\left(R^{2}=0.80\right)$ and the regression equation as follows: $y=-18.238 x^{2}+755.67 x-3953.3$ (Figure 2).

As shown in Figure 3, among all salinity levels at day-15, the highest population growth rate (0.518) of $O$. nana was reported with the salinity level of $20 \mathrm{ppt}$ and the increase was time-dependent (with $\mathrm{R}^{2}=0.993$ and $\mathrm{y}=0.107 \mathrm{x}-0.114$ ), followed by $25 \mathrm{ppt}$ (0.462), $15 \mathrm{ppt}(0.358), 30 \mathrm{ppt}(0.195), 10 \mathrm{ppt}(-0.215)$, and the lowest was at $5 \mathrm{ppt}(-0.691)$ (Figure 3). The effect of salinity was a second-order polynomial pattern with $R^{2}=0.98$ and the regression equation is $y=-0.0044 x^{2}+0.1935 x-1.5955$ (Figure 4).

The percentages of the population composition of $O$. nana cultured on different salinity levels (Figure 5) revealed significant differences between the developmental stages (male, female, nauplii, and copepodite). Copepoda O. nana cultured on salinity levels of 20, 25, and 30 ppt exhibited the highest significant percentages of nauplii $(18.67 \%, 13.59 \%$, and $11.33 \%$, respectively) and copepodite $(16.65 \%, 14.33 \%$, and $10.33 \%$, respectively), while the salinity levels of 15, 10, and 5 ppt exhibited the lowest significant percentages of nauplii $(3.33 \%, 2.00 \%$, and $1.42 \%$, respectively) and copepodite $(2.65 \%, 2.34 \%, 2.03 \%$, respectively), as presented in Figure 5. 


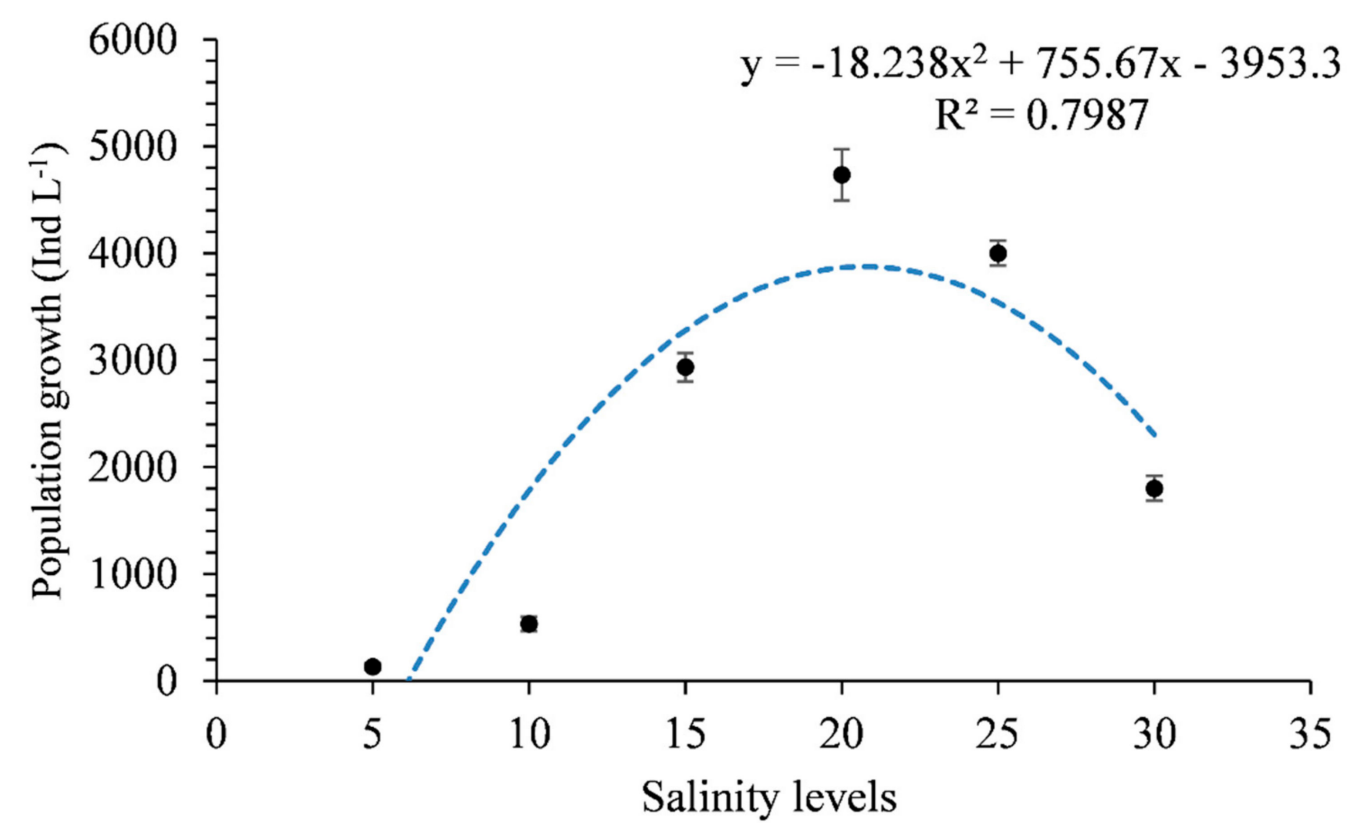

Figure 2. Polynomial second-order regression of Copepoda, Oithona nana, population growth reared at different salinity levels after the 15 days of the experiment.

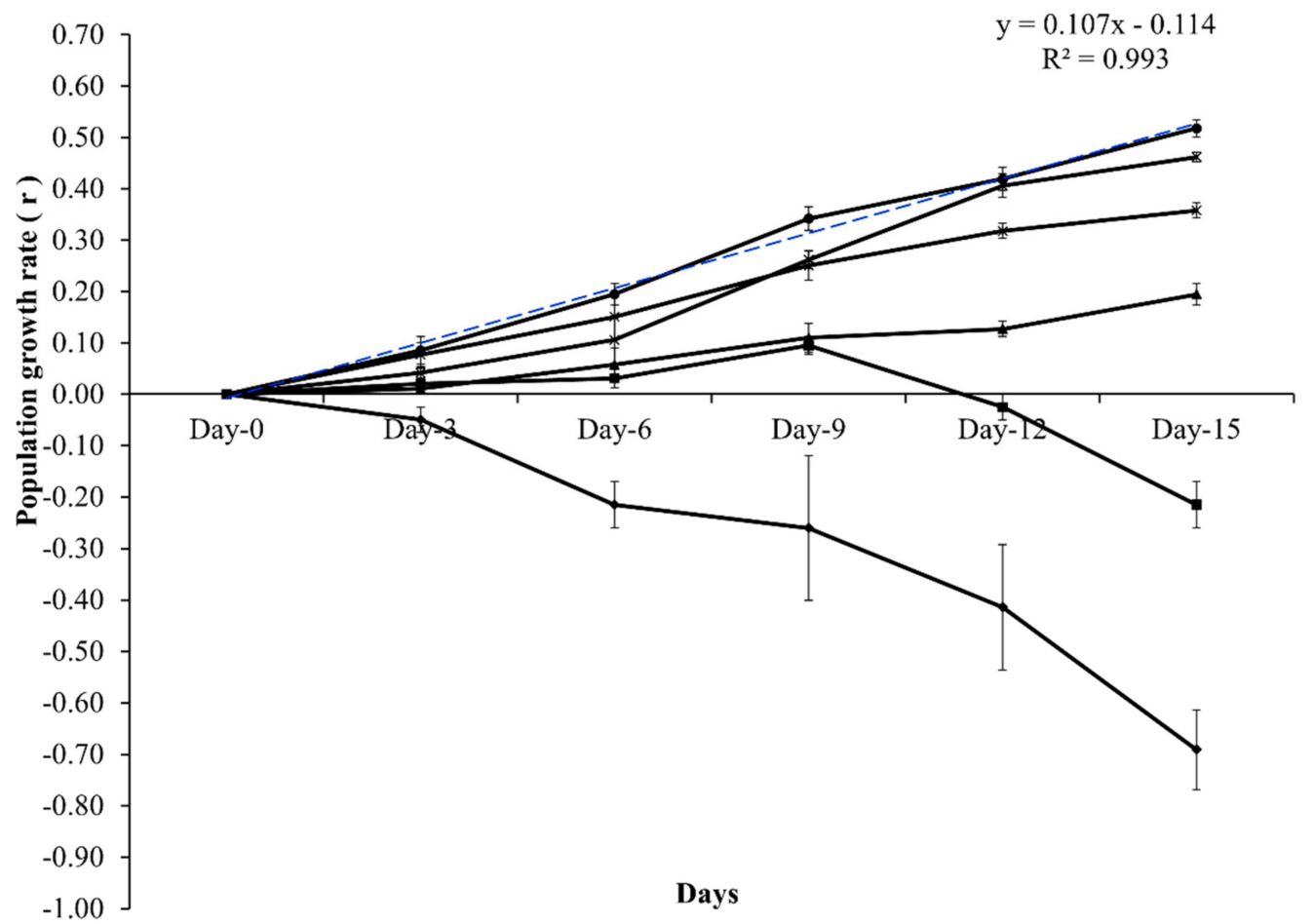

Figure 3. Effect of different salinity levels on the population growth rate $(r)$ of Copepoda, Oithona nana. 


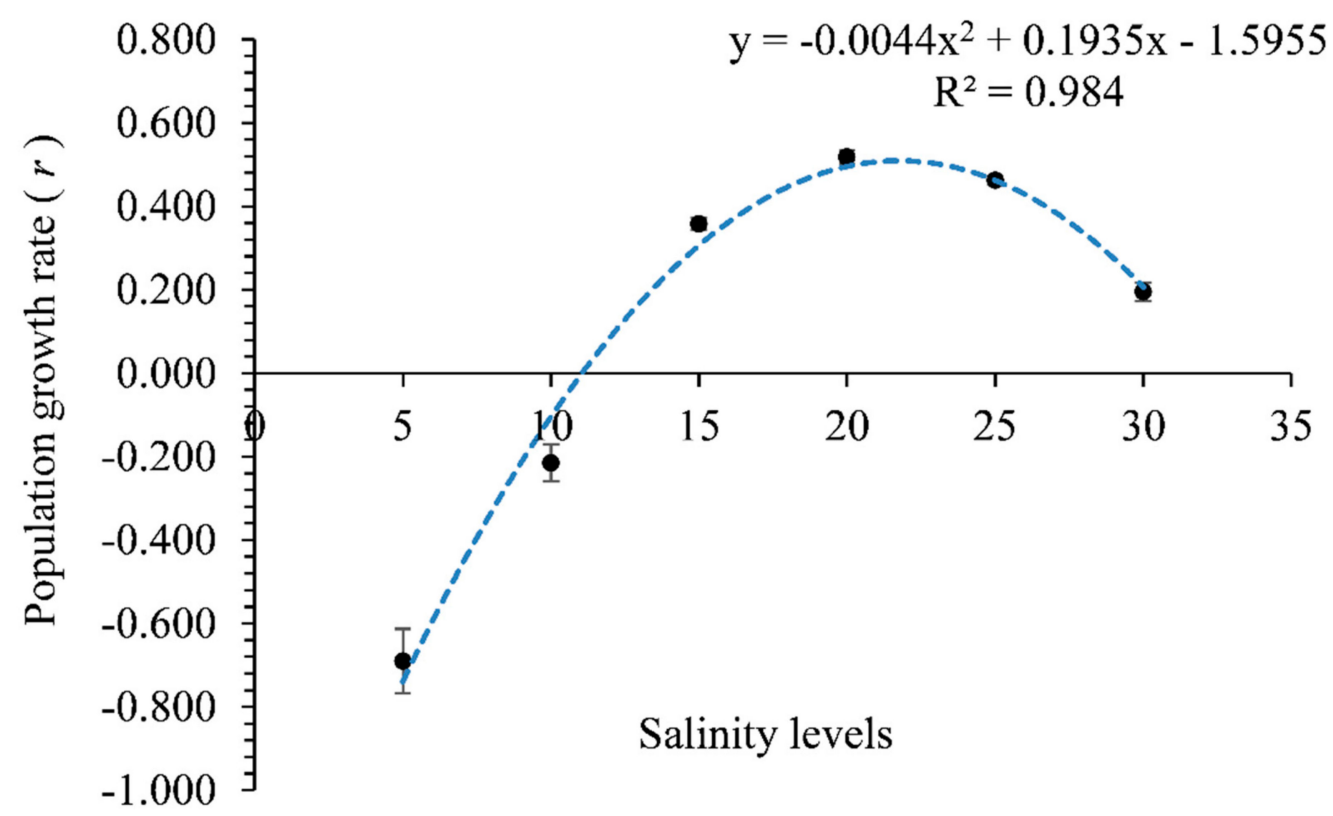

Figure 4. Polynomial second-order regression of Copepoda, Oithona nana, population growth rate $(r)$ reared at different salinity levels after the 15 days of the experiment.

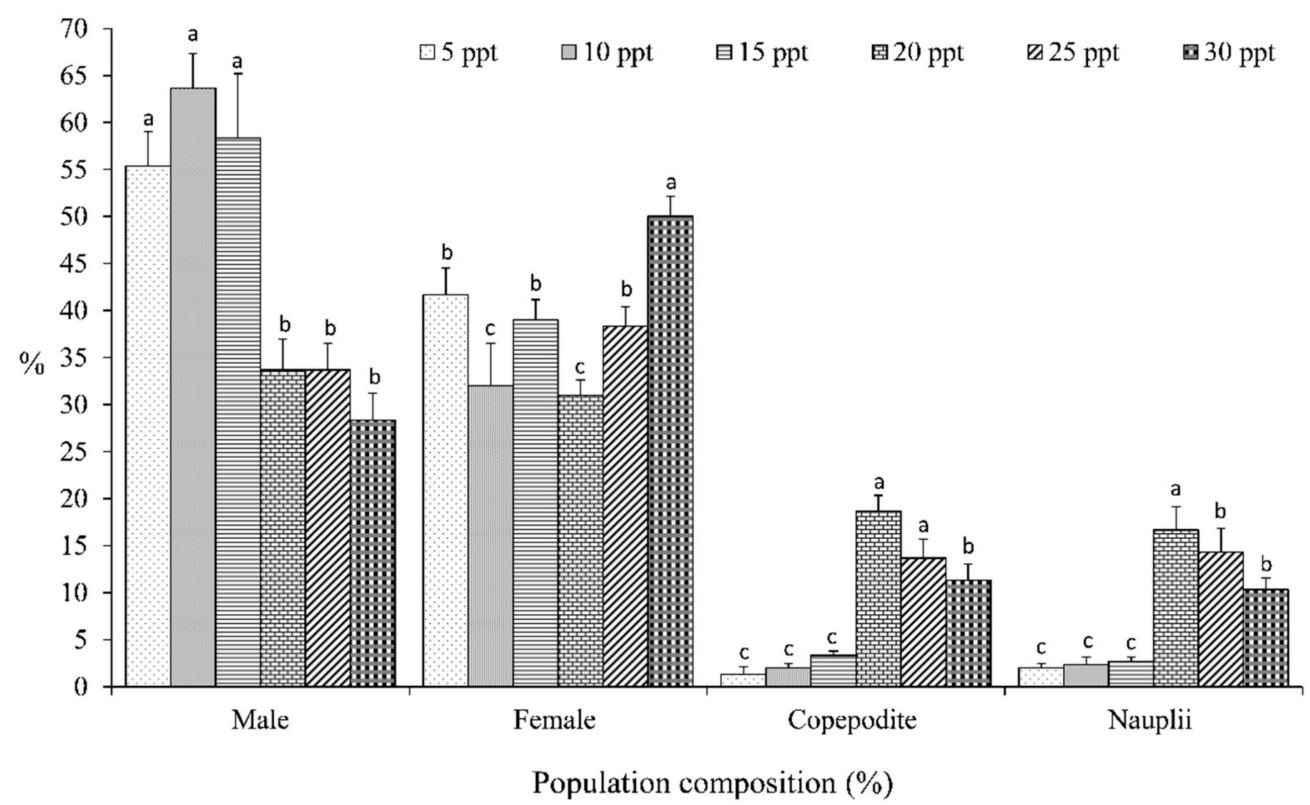

Figure 5. Effect of different salinity levels on the percentage of developmental stages of Copepoda, Oithona nana. Data are presented as the mean \pm standard errors. The letters $(a, a b, b$, and $c)$ above each bar indicate the significant differences $(p \leq 0.05)$ between the developmental stages (adult males, adult females, nauplii, and copepodites) at different salinities.

\section{Discussion}

Copepoda Oithona sp. is an egg-bearing species with a global distribution [40], and is the prevailing copepod in many tropical, subtropical, temperate coastal marine, and estuarine environments [11,45,46]. Oithona nana is considered one of the most appropriate species for mass production in marine hatcheries [47,48]. The low yields, long generation time, and seasonal variations in production under certain conditions are the major obstacles limiting the success of the farming of aquatic organisms $[3,11,49,50]$.

Studying the effects of the salinity on the different growth population parameters, such as population growth and growth rates, of copepod species might clarify the pop- 
ulation dynamics in extensive aquaculture ponds or their wild habitats. In addition, a comprehension of ideal salinity could improve copepod productivity in aquaculture environments [39]. In the current study, different salinity levels (5, 10, 15, 20, 25, and $30 \mathrm{ppt})$ were used to determine the optimal salinity level for the population growth, population growth rate, and population composition of the copepod, $O$. nana. The results disclosed that the salinity levels significantly affected the population growth, population growth rate, and population composition of O. nana (Figures 1-3).

In the current study, after a 15-day culture period, $O$. nana cultured with a salinity level of 20 ppt showed the highest significant population growth (4733 ind. $\mathrm{L}^{-1}, \mathrm{R}^{2}=0.962$ ) and growth rate $\left(0.518, \mathrm{R}^{2}=993\right)$, followed by $25 \mathrm{ppt}\left(4000\right.$ ind. $\mathrm{L}^{-1}, 0.462$, respectively). In contrast, the lowest significant population growth and growth rate were revealed in both the low- and high-salinity levels of 5, 10, 15, and 30 ppt. Our results are in line with the results of Pan Allam et al. [51], who reported a significantly lower population growth of Cyclopoida copepod, A. royi, was obtained in both the low- and high-salinity levels of 5, 30, and 35 ppt, after a 14-day culture period. Moreover, Santhanam et al. [29] cited that the ideal population of copepod, O. rigida, was maintained between 28 and 34 ppt, decreasing the salinity to less than 20 ppt significantly reduced the population, and the $O$. rigida population disappeared in the culture tanks when the salinity was decreased to less than 10 ppt.

In estuary habitats, salinity variation is the pivotal factor that affects the distribution of copepod populations. The differences in salinity tolerance demonstrate the distribution of prevalent copepod species in salinity gradients [52]. In defining the feasibility of copepod species to be utilized as live prey in aquaculture, it is necessary to understand the effects different salinities have on production parameters. Many copepod species can survive in different conditions while having very different productivity [3]. Having wide salinity tolerance is a very useful feature for the live prey in aquaculture and allows copepods to be fed to cultured larvae at different salinity levels $[38,53]$.

The findings of the current study indicate that the highest developmental-stage percentages of nauplii and copepodites of copepod, $O$. nana, were found when cultured at the salinity level of 20 ppt followed by 25 ppt, while salinity levels lower than 20 ppt $(5,10$, and $15 \mathrm{ppt}$ ) showed very low developmental-stage percentages. Our results agree with Santhanam et al. [29], who reported that salinity levels strongly influence the population and developmental stages of copepod, $O$. rigida, with consideration of lower salinity resulting in longer development times. The authors of [38] report on the salinity affecting the time to maturation, percentage of females, and total nauplii produced by copepod, Pseudodiaptomus pelagicus.

Our results conclude that the adult copepods, $O$. nana, were unable to tolerate rapid changes in the salinity from 30 ppt to lower than 15 ppt. These findings show that $O$. nana is able to resist sudden changes in the salinity levels but displays a limit to optimal tolerance of 20 ppt. These findings could be attributed to the physiological stress, the additional osmoregulation, and respiration demands at these salinities. Our findings agree with [38], who reported that copepod $P$. pelagicus adults can withstand abrupt changes in salinity levels from 35 to $15 \mathrm{~g} \mathrm{~L}^{-1}$ and up to $48 \mathrm{~g} \mathrm{~L}^{-1}$. In the current study, the total nauplii produced at the salinity levels of 20 and 25 ppt were more than double the number produced at 30 , 15,10 , and 5 ppt, although there was a high variation [38]. Chen et al. [34] cited that adult copepods, P. annandalei, were not capable of producing nauplii at 35 ppt. Payne et al. [54] reported that cultured G. imparipes were not able to produce nauplii at four salinity levels.

\section{Conclusions}

Studying the effects of different salinity levels on the different growth population parameters of the copepod species is useful in clarifying its population dynamics in marine aquaculture, as well as defining its feasibility to be utilized as live prey in marine hatcheries. The salinity levels of the culture water significantly influence the population growth, population growth rate, and the percentages of developmental stages of cultured O. nana. 
The findings of our study could be used to develop and improve the culture conditions of copepod, O. nana. The current study concluded that copepod, O. nana, can withstand abrupt changes in the salinity, but exhibits limits to its tolerance, with an optimal salinity level of $20 \mathrm{ppt}$.

Author Contributions: Conceptualization: F.I.M., M.A.E., M.M. and M.A.; data curation, M.M. and A.G.; formal analysis, F.I.M., M.M. and M.A.; funding acquisition, A.T.M. and A.G.; investigation, M.M. and M.A.; methodology, M.A.E., M.M. and M.A.; project administration, F.I.M., M.A.E., A.T.M., A.G. and M.A.; resources, M.M., A.G. and M.A.; software, A.T.M.; supervision, F.I.M. and M.A.E.; validation, F.I.M. and M.A.E.; writing—original draft, M.M. and M.A.; writing—review and editing, M.M., A.T.M. and A.G. All authors have read and agreed to the published version of the manuscript.

Funding: This research was funded by Taif University, Researchers Supporting Project number TURSP-2020/39, Taif University, Taif, Saudi Arabia.

Institutional Review Board Statement: The study was conducted according to the guidelines of the Declaration of Helsinki, and approved by the Committee of Local Experiment Animal Care, Faculty of Agriculture, Kafrelsheikh University, Egypt, (protocol code 4/2016EC).

Informed Consent Statement: Not applicable.

Data Availability Statement: The data that support the findings of this study are available from the authors upon request.

Acknowledgments: The authors appreciate Taif University Researchers Supporting Project number TURSP-2020/39, Taif University, Taif, Saudi Arabia.

Conflicts of Interest: The authors declare no conflict of interest.

\section{References}

1. El-Sayed, A.-F.M. Tilapia Culture, 2nd ed.; Elsevier: Amsterdam, The Netherlands; Academic Press: London, UK, 2019.

2. Abbas, E.M.; Ali, F.S.; Desouky, M.G.; Ashour, M.; El-Shafei, A.; Maaty, M.M.; Sharawy, Z.Z. Novel Comprehensive Molecular and Ecological Study Introducing Coastal Mud Shrimp (Solenocera Crassicornis) Recorded at the Gulf of Suez, Egypt. J. Mar. Sci. Eng. 2020, 9, 9. [CrossRef]

3. Støttrup, J. The elusive copepods: Their production and suitability in marine aquaculture. Aquac. Res. 2000, 31, 703-711. [CrossRef]

4. Olivotto, I.; Tokle, N.; Nozzi, V.; Cossignani, L.; Carnevali, O. Preserved copepods as a new technology for the marine ornamental fish aquaculture: A feeding study. Aquaculture 2010, 308, 124-131. [CrossRef]

5. Abate, T.G.; Nielsen, R.; Nielsen, M.; Jepsen, P.M.; Hansen, B.W. A cost-effectiveness analysis of live feeds in juvenile turbot Scophthalmus maximus (Linnaeus, 1758) farming: Copepods versus A rtemia. Aquac. Nutr. 2016, 22, 899-910. [CrossRef]

6. Sharawy, Z.Z.; Ashour, M.; Abbas, E.; Ashry, O.; Helal, M.; Nazmi, H.; Kelany, M.; Kamel, A.; Hassaan, M.; Rossi, W., Jr.; et al. Effects of dietary marine microalgae, Tetraselmis suecica, on production, gene expression, protein markers and bacterial count of Pacific white shrimp Litopenaeus vannamei. Aquac. Res. 2020, 51, 2216-2228. [CrossRef]

7. Zaki, M.A.; Ashour, M.; Heneash, A.M.; Mabrouk, M.M.; Alprol, A.E.; Khairy, H.M.; Nour, A.M.; Mansour, A.T.; Hassanien, H.A.; Gaber, A.; et al. Potential Applications of Native Cyanobacterium Isolate (Arthrospira platensis NIOF17/003) for Biodiesel Production and Utilization of Its Byproduct in Marine Rotifer (Brachionus plicatilis) Production. Sustainability 2021, 13, 1769. [CrossRef]

8. Abdel Rahman, H.; Abdel Razek, A.; AbouZeid, A.; Ashour, M. Optimum growth conditions of three isolated diatoms species Skeletonema costatum, Chaetoceros calcitrans and Detonula confervacea and their utilization as feed for marine penaeid shrimp larvae. Egypt. J. Aquat. Res. 2010, 36, 161-183.

9. Abo-Taleb, H.; Ashour, M.; El-Shafei, A.; Alataway, A.; Maaty, M.M.; Abo-Taleb, H. Biodiversity of Calanoida Copepoda in Different Habitats of the North-Western Red Sea (Hurghada Shelf). Water 2020, 12, 656. [CrossRef]

10. Abo-Taleb, H.A.; Zeina, A.F.; Ashour, M.; Mabrouk, M.M.; Sallam, A.E.; El-Feky, M.M.M. Isolation and cultivation of the freshwater amphipod Gammarus pulex (Linnaeus, 1758), with an evaluation of its chemical and nutritional content. Egypt. J. Aquat. Biol. Fish. 2020, 24, 69-82. [CrossRef]

11. Ajiboye, O.O.; Yakubu, A.F.; Adams, T.E.; Olaji, E.D.; Nwogu, N.A. A review of the use of copepods in marine fish larviculture. Rev. Fish Biol. Fish. 2010, 21, 225-246. [CrossRef]

12. Ashour, M.; Abo-Taleb, H.; Abou-Mahmoud, M.; El-Feky, M. Effect of the integration between plankton natural productivity and environmental assessment of irrigation water, El-Mahmoudia Canal, on aquaculture potential of Oreochromis niloticus. Turk. J. Fish. Aquat. Sci. 2018, 18, 1163-1175. [CrossRef] 
13. Ashour, M.; Elshobary, M.E.; El-Shenody, R.; Kamil, A.-W.; Abomohra, A.E.-F. Evaluation of a native oleaginous marine microalga Nannochloropsis oceanica for dual use in biodiesel production and aquaculture feed. Biomass Bioenergy 2019, 120, $439-447$. [CrossRef]

14. Sorgeloos, P.; Baeza-Mesa, M.; Bossuyt, E.; Bruggeman, E.; Dobbeleir, J.; Versichele, D.; Laviña, E.; Bernardino, A. Culture of Artemia on rice bran: The conversion of a waste-product into highly nutritive animal protein. Aquaculture 1980, 21, 393-396. [CrossRef]

15. Elshobary, M.E.; El-Shenody, R.A.; Ashour, M.; Zabed, H.M.; Qi, X. Antimicrobial and antioxidant characterization of bioactive components from Chlorococcum minutum. Food Biosci. 2020, 35, 100567. [CrossRef]

16. El-Gamal, M.M.; Othman, S.I.; Abdel-Rahim, M.M.; Mansour, A.T.; Alsaqufi, A.S.; El Atafy, M.M.; Mona, M.H.; Allam, A.A. Palaemon and artemia supplemented diet enhances sea bass, Dicentrarchus labrax, broodstock reproductive performance and egg quality. Aquac. Rep. 2020, 16, 100290. [CrossRef]

17. Abdel-Rahim, M.M.; Mansour, A.T.; Mona, M.H.; El-Gamal, M.M.; El Atafy, M.M. To what extent can maternal inherited immunity acquired from a crustacean-enhanced diet improve the performance and vitality of the offspring and enhance profitability of European Sea bass (Dicentrarchus labrax)? J. World Aquac. Soc. 2019, 50, 550-574. [CrossRef]

18. Yamaguchi, A.; Matsuno, K.; Homma, T. Spatial changes in the vertical distribution of calanoid copepods down to great depths in the North Pacific. Zool. Stud. 2015, 54, e13. [CrossRef]

19. Heneash, A.; Ashour, M.; Matar, M. Effect of Un-live Microalgal diet, Nannochloropsis oculata and Arthrospira (Spirulina) platensis, Comparing to Yeast on Population of Rotifer, Brachionus plicatilis. Mediterr. Aquac. J. 2015, 7, 48-54. [CrossRef]

20. Temperoni, B.; Diovisalvi, N.; Negri, R.; Viñas, M. Seasonal production of Oithona nana Giesbrecht, 1893 (Copepoda: Cyclopoida) in temperate coastal waters off Argentina. J. Plankton Res. 2010, 33, 729-740. [CrossRef]

21. Inshida, S. Taxonomy and distribution of the family Oithonidae (Copepoda, Cyclopoida) in the Pacific and Indian Oceans. Bull. Ocean Res. Inst. Univ. Tokyo 1985, 20, 1-167.

22. Lampitt, R.S.; Gamble, J.C. Diet and respiration of the small planktonic marine copepod Oithona nana. Mar. Biol. 1982, 66, 185-190. [CrossRef]

23. Williams, J.A.; Muxagata, E. The seasonal abundance and production of Oithona nana (Copepoda:Cyclopoida) in Southampton Water. J. Plankton Res. 2006, 28, 1055-1065. [CrossRef]

24. Miyashita, L.K.; Júnior, M.D.M.; Lopes, R.M. Estuarine and oceanic influences on copepod abundance and production of a subtropical coastal area. J. Plankton Res. 2009, 31, 815-826. [CrossRef]

25. Farhadian, O.; Md Yusoff, F.; Arshad, A. Effects of salinity, temperature, light intensity and light regimes on production, growth and reproductive parameters of Apocyclops dengizicus. Iran. J. Fish. Sci. 2014, 13, 30-46.

26. Morehead, D. Copepod culture workshop in Hawaii. Austasia Aquac. 2004, 18, 46-49.

27. Ashour, M.; Kamel, A. Enhance growth and biochemical composition of Nannochloropsis oceanica cultured under nutrient limitation using commercial agricultural fertilizers. J. Mar. Sci. Res. Dev. 2017, 7, 233.

28. Molejón, O.H.; Alvarez-Lajonchère, L. Culture experiments with Oithona oculata Farran, 1913 (Copepoda: Cyclopoida), and its advantages as food for marine fish larvae. Aquaculture 2003, 219, 471-483. [CrossRef]

29. Santhanam, P.; Perumal, P. Effect of temperature, salinity and algal food concentration on population density, growth and survival of marine copepod Oithona rigida Giesbrecht. Indian J. Geo-Mar. Sci. 2012, 41, 369-376.

30. Isla, J.A.; Perissinotto, R. Effects of temperature, salinity and sex on the basal metabolic rate of the estuarine copepod Pseudodiaptomus hessei. J. Plankton Res. 2004, 26, 579-583. [CrossRef]

31. Souza-Santos, L.P.; Pastor, J.M.; Ferreira, N.G.; Costa, W.M.; Araújo-Castro, C.M.; Santos, P.J. Developing the harpacticoid copepod Tisbe biminiensis culture: Testing for salinity tolerance, ration levels, presence of sediment and density dependent analyses. Aquac. Res. 2006, 37, 1516-1523. [CrossRef]

32. Peck, M.A.; Holste, L. Effects of salinity, photoperiod and adult stocking density on egg production and egg hatching success in Acartia tonsa (Calanoida: Copepoda): Optimizing intensive cultures. Aquaculture 2006, 255, 341-350. [CrossRef]

33. Holste, L.; Peck, M.A. The effects of temperature and salinity on egg production and hatching success of Baltic Acartia tonsa (Copepoda: Calanoida): A laboratory investigation. Mar. Biol. 2006, 148, 1061-1070. [CrossRef]

34. Chen, Q.; Sheng, J.; Lin, Q.; Gao, Y.; Lv, J. Effect of salinity on reproduction and survival of the copepod Pseudodiaptomus annandalei Sewell, 1919. Aquaculture 2006, 258, 575-582. [CrossRef]

35. Sullivan, B.K.; Costello, J.H.; Van Keuren, D. Seasonality of the copepods Acartia hudsonica and Acartia tonsa in Narragansett Bay, RI, USA during a period of climate change. Estuar. Coast. Shelf Sci. 2007, 73, 259-267. [CrossRef]

36. Milione, M.; Zeng, C. The effects of temperature and salinity on population growth and egg hatching success of the tropical calanoid copepod, Acartia sinjiensis. Aquaculture 2008, 275, 116-123. [CrossRef]

37. Sun, X.; Sun, S.; Li, C.; Zhang, G. Seasonal and spatial variation in abundance and egg production of Paracalanus parvus (Copepoda: Calanoida) in/out Jiaozhou Bay, China. Estuar. Coast. Shelf Sci. 2008, 79, 637-643. [CrossRef]

38. Ohs, C.L.; Rhyne, A.L.; Grabe, S.W.; DiMaggio, M.A.; Stenn, E. Effects of salinity on reproduction and survival of the calanoid copepod Pseudodiaptomus pelagicus. Aquaculture 2010, 307, 219-224. [CrossRef]

39. Pan, Y.-J.; Souissi, A.; Souissi, S.; Hwang, J.-S. Effects of salinity on the reproductive performance of Apocyclops royi (Copepoda, Cyclopoida). J. Exp. Mar. Biol. Ecol. 2016, 475, 108-113. [CrossRef] 
40. Jean, J.J.; Lincy, A.; Lipton, A.; Chandran, A. Developmental Stages Observed During Experimental Culture of the Egg Bearing Cyclopoid Copepod Oithona Similis (Claus, 1866); NISCAIR-CSIR: New Delhi, India, 2016.

41. Tseng, L.-C.; Dahms, H.-U.; Chen, Q.-C.; Hwang, J.-S. Copepod feeding study in the upper layer of the tropical South China Sea. Helgol. Mar. Res. 2009, 63, 327-337. [CrossRef]

42. El-Khodary, G.M.; Mona, M.M.; El-Sayed, H.S.; Ghoneim, A.Z. Phylogenetic identification and assessment of the nutritional value of different diets for a copepod species isolated from Eastern Harbor coastal region. Egypt. J. Aquat. Res. 2020, 46, 173-180. [CrossRef]

43. Magouz, F.I.; Essa, M.A.; Matter, M.; Mansour, A.T.; Alkafafy, M.; Ashour, M. Population dynamics, fecundity and fatty acid composition of Oithona nana (Cyclopoida, Copepoda), fed on different diets. Animals 2021, 11, 1188. [CrossRef]

44. Yin, X.W.; Min, W.W.; Lin, H.J.; Chen, W. Population dynamics, protein content, and lipid composition of Brachionus plicatilis fed artificial macroalgal detritus and Nannochloropsis sp. diets. Aquaculture 2013, 380-383, 62-69. [CrossRef]

45. Paffenhöfer, G.-A.; Mazzocchi, M. On some aspects of the behaviour of Oithona plumifera (Copepoda: Cyclopoida). J. Plankton Res. 2002, 24, 129-135. [CrossRef]

46. Cornils, A.; Wend-Heckmann, B. First report of the planktonic copepod Oithona davisae in the northern Wadden Sea (North Sea): Evidence for recent invasion? Helgol. Mar. Res. 2015, 69, 243-248. [CrossRef]

47. Chilmawati, D. The Effect of Different Diet of Phytoplankton Cells on Growth Performance of Copepod, Oithona sp. in Semi-mass Culture. Aquat. Procedia 2016, 7, 39-45. [CrossRef]

48. Magouz, F.I.M.; Essa, M.A.; El-Shafei, A.; Mansour, A.T.; Mahmoud, S.m.; Ashour, M. Effect of extended feeding with live copepods, Oithona nana, and Artemia franciscana on the growth performance, intestine histology, and economic viability of european seabass (Dicentrarchus labrax) postlarvae. Fresenius Environ. Bull. 2021, 30, 7106-7116.

49. El-Shenody, R.A.; Ashour, M.; Ghobara, M.M.E. Evaluating the chemical composition and antioxidant activity of three Egyptian seaweeds: Dictyota dichotoma, Turbinaria decurrens, and Laurencia obtusa. Braz. J. Food Technol. 2019, 22, 2018203. [CrossRef]

50. Ashour, M.; Mabrouk, M.M.; Ayoub, H.F.; El-Feky, M.M.; Zaki, S.Z.; Hoseinifar, S.H.; Rossi, W.; Van Doan, H.; El-Haroun, E.; Goda, A.M.-S. Effect of dietary seaweed extract supplementation on growth, feed utilization, hematological indices, and non-specific immunity of Nile Tilapia, Oreochromis niloticus challenged with Aeromonas hydrophila. Environ. Boil. Fishes 2020, 32, 1-13. [CrossRef]

51. Allam, B.W.; Khalil, H.S.; Mansour, A.T.; Srour, T.M.; Omar, E.A.; Nour, A.A.M. Impact of substitution of fish meal by high protein distillers dried grains on growth performance, plasma protein and economic benefit of striped catfish (Pangasianodon hypophthalmus). Aquaculture 2020, 517, 734792. [CrossRef]

52. Devreker, D.; Souissi, S.; Winkler, G.; Forget-Leray, J.; Leboulenger, F. Effects of salinity, temperature and individual variability on the reproduction of Eurytemora affinis (Copepoda; Calanoida) from the Seine estuary: A laboratory study. J. Exp. Mar. Biol. Ecol. 2009, 368, 113-123. [CrossRef]

53. Jepsen, P.M.; Thoisen, C.V.; Carron-Cabaret, T.; Pinyol-Gallemí, A.; Nielsen, S.L.; Hansen, B.W. Effects of salinity, commercial salts, and water type on cultivation of the cryptophyte microalgae Rhodomonas salina and the calanoid copepod Acartia tonsa. J. World Aquac. Soc. 2019, 50, 104-118. [CrossRef]

54. Payne, M.; Rippingale, R. Effects of salinity, cold storage and enrichment on the calanoid copepod Gladioferens imparipes. Aquaculture 2001, 201, 251-262. [CrossRef] 